\title{
Evolution of Teaching Approaches for Science, Engineering and Technology within an Online Environment: A Review
}

Rendani Wilson Maladzhi*, Grace Mukondeleli Kanakana-Katumba

University of South Africa, Department of Mechanical and Industrial Engineering, Johannesburg, South Africa

\author{
A R T I C L E IN F O \\ Article history: \\ Received: 30 August, 2020 \\ Accepted: 25 November, 2020 \\ Online: 16 December, 2020
}

Keywords:

Augmented reality

Online teaching and learning

Science

Engineering and technology

Teaching Approaches

Virtual reality

Virtual laboratory

\begin{abstract}
A B S T R A C T
The emergence of the COVID-19 pandemic earlier this year destabilised the operations in the education sector, particularly in institutions of higher learning. Most of these institutions are now expected to teach online, assess their students using non-venue examinations and offer remote laboratory practical and experiments. However, many of these institutions were not prepared for such dynamic change in a such short space of time. Consequently, most of the institutions moved their mid-year examinations to the October/November period. In addition, they are finding methods to conduct laboratory practical and experiments. Prominent researchers agree that institutions of higher learning are challenged by the current dispensation where academics are expected to implement new pedagogical approaches and take advantage of information and communications technology (ICT) for teaching and learning. Every module requires a specific teaching method, as a result, academics need to know about various methods available. Generally, the sciences and engineering modules are taught within the classroom environment and require experiential platforms to solidify the theoretical knowledge gained. The current study is aimed at assessing the evolution of teaching approaches and technologies in distance education regarding online delivery particularly in science, engineering and technology. Various search engines such as Google Scholar, Scopus, Sabinet, ProQuest and EBSCO were used to obtain relevant literature to depict popular teaching approaches and the relevant technologies. In order to access relevant literature, various key strings were used. The findings of the study revealed problem-based, apprenticeship and experimental, and competency-based learning as the most popular teaching approaches, particularly between 2010 and 2020. Project-based learning, case-based learning and communities of practice equally share the third position followed by integrative learning. Students and academics show that instant feedback provided by virtual labs yielded encouraging results. This shows that many students and their academics prefer the introduction of the virtual labs in their learning environment, especially from 2012 until recent. The literature further confirms the current findings that institutions of higher learning need to equip academics to be able to integrate technology within their teaching methods for students to continue to learn at ease.
\end{abstract}

\section{Introduction}

This paper is an extension of "Online Learning Approaches for Science, Engineering and Technology in Distance Education" presented at the IEEM 2019 Conference in Macau [1]. Higher education institutions are currently endorsing online courses as a business reality since their budgets are now linked to their enrolments [2]. The introduction of an online learning

*Corresponding Author: Rendani Wilson Maladzhi, maladrw@unisa.ac.za environment has become a long-term business strategy [3] for many institutions worldwide, to the extent that the proportion of students taking at least one online course has increased from 1 in 10 to nearly one-third in 2010 [3]. The accessibility of the internet of things (IOT) in universities worldwide caused them to invest in elearning systems to enhance their teaching activities to improve their students' learning experiences and performance [4]. Online teaching and learning environments have brought some mixed feelings to students who believe that video lecturers slightly outperform face- 
to-face lecturers [5] and some students feel interactive online videos are even better [6]. In addition, others feel that online homework is as effective as paper and pencil [7], [8] and intelligent tutoring is seen to be as effective as human tutors [9]. The dynamics above describe how teaching and learning have evolved over the years with reference to five generations of distance education.

The transition through the five generations of distance education has, over the years, witnessed a change in the use the delivery media of teaching and learning that ranged from text and images, sound and video, live television broadcasting to Web 2.0 interactive online technologies such as podcasts, video conferences, virtual spaces etc. [10]-[12]. Based on the above stated transition, the exchange of information between academics and students remained key, but the mode of delivery and the technological tools made all the difference. Hence, various disciplines require different teaching methods accompanied by various technological tools, as is the case with the current research that focusses on the science, engineering and technology sector. Teaching science, engineering and technology in an online environment has been considered an impossible mission for several years [13]. It is a fact that the sciences and engineering disciplines customarily require laboratory work where students perform their practicals to demonstrate their understanding of the theoretical knowledge.

In another instance, an Engineering Graphics Online Course was first introduced in Tianjin University, where 20 colleges and universities participated to cater for almost 1500 students. As a result, this online environment enabled educational resources to be shared in different areas while quality teaching of engineering graphics was made possible [15].

Laboratory classes are an essential component of most science and engineering courses with the potential to achieve several practical and theoretical objectives [16]. Arguably, students must not only learn manipulative techniques, but also link theory to practice, solve different kind of problems, interpret data, interact with staff and other students, and successfully navigate the lab [16]. Learning in this situation can be greatly assisted by academics who are able to guide students through this complex process. However, the effectiveness of laboratory classes is often not achieved to their full potential [16].

The emergence of the COVID-19 pandemic brough along uncertainties for the institutions of higher learning regarding teaching activities and practical and laboratory experiments. On the other hand, it presented distance education institutions with an opportunity to introduce non-venue-based assessments and remote practical and laboratory experiments. The traditional teaching and learning platform greatly benefited by the development of internet and ICT capabilities [17]. Virtual labs afforded students an opportunity to revive their curiosity and creativity while learning from their own respective spaces [18]. The mode of teaching such as synchronous and asynchronous modes made it possible for teaching and learning to take place at a distance. As such, students taught through the asynchronous mode displayed higher cognitive achievement while those taught through the synchronous e-learning mode displayed improved skills acquisition [19]. Hence, the importance of academics understanding the engineering, science and technology (SET) environment to better equip the students appropriately. A synchronous mode of delivery facilitates teaching and learning in real time, whereas an asynchronous mode requires self-paced teaching and learning activities that make use of email, blogs, wikis, discussion boards, web-supported textbooks, hypertext documents, audio or video courses, and social networking using Web 2.0. [19]. The emergence of Massive Open Online Courses (MOOCs) has made it possible for students all over the world to access free credible multimedia resources utilised by academics from recognised universities across the world [20].

Theories about teaching methods do not exist, particularly in post-secondary level, but apprenticeships that resemble learning by teaching, do exist [21]. However, other researchers viewed apprenticeship or experiential learning or learning by doing as an opportunity for SET learners to engage in active learning while reflecting and putting into practice what they learned in the classroom or outside of the classroom [22]. Traditionally, SET experiential learning methods such as laboratory work, workshops; apprenticeships; problem-based learning; case-based learning; project-based learning; inquiry-based learning; and cooperative learning [21], were mainly found within the SET environment. Additive manufacturing [23], augmented reality, virtual labs, online teaching modules and educational aids (Kit) [24]; modelling activities by 3D printers [25]; Engineering Graphics Online Course [15]; online tutorial system [30]; flipped classroom [23]; virtual simulation teaching [26]; virtual reality; the Digital Engineering module were all transformed it into an online teaching environment.

The purpose of this paper is to determine teaching approaches in SET that are gaining popularity due to the evolution of technology within the online environment to improve students' performance. The technological advances over the years contributed positively in turning traditional teaching approaches in science, engineering and technology into suitable online learning.

\section{Literature Review}

Teaching and learning have evolved over the years due to technological advancements and knowledge transfer between academics and students. It is a fact that teaching modalities also depend on various disciplines offered in various institutions of higher learning.

Experiential learning took a form of learning by doing and as such, is preferable in the SET environment [21]. However, its successful implementation particularly in an online environment requires virtual technologies. As a result, literature that covers teaching methods and respective technologies are viewed as follows: integrative, apprenticeship and experiential learning, problem-based learning, project-based learning, case-based learning, inquiry-based learning, competency-based learning and communities of practice. It has now become apparent that technologies that enhance teaching and learning be exposed to the world for the benefit of the SET sector.

\subsection{Integrative approach}

The integrative approach is regarded as an innovative practice due to its ability to introduce a concerted approach to mathematics 1208 
and science academics in the teaching and learning environment [27]. It permits students to learn about life's origin, then life's evolution, and thereafter about the future of life and humankind in the Earth and Life Sciences, Mathematical modelling concepts, such as the modelling cycle, solves problems regarding real-life situations [27]. Some of the characteristics of the interactive approach are like those in seminars and tutorial [27]. The emergence of distance learning through online environments calls for teaching activities to be conducted differently. In other instances, the teaching of mathematics education in engineering spaces is enriched through modelling activities by $3 \mathrm{D}$ printers [25]. As a result, academics should be provided with technological skills to function better and teach effectively.

Virtual learning systems (VLSs) in the academic fraternity play a similar role as enterprise resource planning systems (ERPSs) in the administration arena [28]. Virtual learning systems are known for their role in the teaching and learning avenues that coordinate activities such as learning objectives, class exercises, quizzes and tests in both synchronous and asynchronous communication [29]. The introduction of online tutorial systems within the Australian universities has seen a tremendous increase in the number of students entering the universities [30]. It is a fact that the new developed online teaching approaches introduced a diverse background of skills, motivations and prior knowledge. In addition, the online tutorial system was found to be instrumental in modules such as engineering physics and mathematics, and as such, students did not only pass their examinations, but it also improved the retention rate of first-year engineering students with the financial benefit to the institution [30].

\subsection{Apprenticeship and experiential learning}

The teaching approaches such as apprenticeship, experiential learning, cooperative learning and adventure learning are commonly used in the fields of SET. They are preferred for their capability to provide students with prospects to experimentally practice their learned experiences [21]. Learning by doing was traditionally instrumental in the mechanical, civil, electrical and electronics vocational fields [21], [27]. However, its transition towards online experimentation and remote/virtual labs presented learners with vast opportunities to control real or virtual equipment at a distance in order to perform scientific experiments [20]. It appears that different researchers refer to virtual laboratories differently; some view it as simulation-based learning, remote experimentation and remote inquiry-based learning [18], [31], [32].

Lack of reputable laboratory experiments contributed negatively to engineering education and resulted in students utilising outdated experiments [18]. The introduction of virtual laboratories gave students an opportunity to make use of good laboratory facilities operated by trained academics as they made use of remote experimentation [18]. It should be noted that virtual laboratories allow students to take ownership of the experiments and the quality control thereof [18]. Virtual laboratories become a multi-institution and yet multidiscipline initiative aimed at benefiting the students within the engineering fields [18]. In its nature, it addresses the issue of lack of good laboratories facilities, as well as trained teachers, by making remote experimentation possible [18]. It provides students with an opportunity to take ownership of teaching and learning space while academics provide minimal guidance. According to [18] and [31], Virtual Laboratory reached over 100000 students, and are accessible after hours [18,31].

It has been proven that virtual experiments are proven to be more beneficial for teaching and learning [33].

Factually, learning is currently shifting from synchronous inclass settings to asynchronous online platforms so that education can be accessible to a wider audience [34]. It is believed that engineering education always requires laboratory work and hands-on practical components that are not possible to conduct online. However, it was only made possible by the introduction of simulations in fluid mechanics laboratories [34].

Virtual reality (VR) puts the user into a computer-created world that seems real [35]. In addition, VR creates an environment in which the user feels and seems to be moving inside a computercreated virtual world in the same way people move in and around a natural environment; while immersed in the virtual world, the user cannot perceive the real one which still surrounds him [36]. The findings on the study conducted by Luo depicted that students enjoyed taking measurements in the laboratory. However, other students on the other hand were sleeping around with nothing to show. As a result, virtual practicals are preferred as opposed to the traditional way of conducting practical work [26] for mechanical, electrical, civil engineering and other qualifications.

Augmented reality (AR) utilises smart devices and applications such as smart phones, tablets, wearable headsets and immersive technologies that enhance information in real-time to become intelligent [37]. It contemplates real-world events with computer-generated digital information by allowing the user to experience the interaction of the two worlds [38]. AR is capable of making required information available, presented and experienced by users 'augmenting the real world with digital information [39]. The practical application of augmented reality proved itself to be economically and technically viable for societal usage [39]. Hence, it is preferred within the mechanical, industrial, electrical, civil and other engineering disciplines.

\subsection{Problem-based learning}

Problem-based learning (PBL) enables the students to gain knowledge about and apply it to different problems they investigate [40]. As they seek solutions for the problems at hand, students have an opportunity to argue and debate based on their own understanding and the acquired facts [40]. PBL teaches students not to depend on their lecturers for information but to rather resort to other sources to make informed decisions. It is important to note that PBL is more suited for student-centred and community-based learning environments [41].

Additive manufacturing (AM) is the preferred technology of teaching used by academics to introduce topics that are industry and academic experts, laboratory and final engineering projects. $\mathrm{AM}$ is a PBL in nature due to its innovative features dealing with devices for people with disabilities. Other PBL-related projects include the development of an opener for medicine containers, a device for pouring liquids for people who have Parkinson's disease, and a 3D puzzle for people who have visual impairments. 
[23]. It has the capability to encourage students' creativity, learning motivation and engagement [23].

The flipped classroom (FCM) has emerged as a learning model that increases students' active learning, collaboration and scaffolding during the learning process through better allocation of teaching time [43]. As such, the FCM method recognises that teaching activities within face-to-face environment should not be about academics teaching but should rather focus on creating an environment for students to effectively collaborate with each other while guided by the academics through scaffolding methods [44], [45]. It is believed that digital technologies have made it possible for teaching and learning to take place without students being confined to a classroom, and that learning can take place from anywhere as long as study material, videos, online quizzes etc. are available.

The FCM method is preferred by both practitioners and researchers in various subjects such as Mathematics, ICT, Social Studies, Humanities etc. [46]-[50], [89].

The results from various studies further confirmed the FCM method is an effective technology that raises the performance of students who face difficulties in face-to-face educational contexts, and equally assists academics and institutions to improve learning conditions [51]. The FCM's nature affords academics an opportunity to scaffolding and create an enabling environment for engagement with hands-on practices [51].

Traditionally, the Digital Engineering lectures were limited to the face-to-face mode of delivery where students only listened to the lecturer delivering the lecture [24]. It was indeed a tremendous challenge since there was no point of demonstrating the application of electronic circuits, digital electronics and high logic circuits for students to apply in industry [24]. The introduction of online teaching methods utilising the Proteus software to enhance skills of learners began to make a difference [24]. Both problem-based learning and competency-based learning suited the Digital Engineering module. This is due to the application of the software that demonstrates teaching and learning activities to students, which also requires both online and off-line learning with computer-based learning assistance [24].

Arguably, teaching practical science at a distance has been a challenge for a while in most institutions across the world. However, in July 2013, the Open University (OU) launched the Wolfson Open Science Laboratory (OSL), which offered a variety of practical science experiences to their distance learning students [13]. With this initiative, students are provided an opportunity to observe, investigate, gather and analyse data. In fact, numerous studies confirmed the effectiveness of PBL because it fostered active learning.

\subsection{Case-based learning}

Case-based learning (CBL) is an interactive group learning pedagogy preferable in various disciplines including business, law, health [14], [52] and in sciences [53]. Case-based learning is defined as an educational approach that allows students to work in small, collaborative groups to solve problems [54]. It is gaining popularity at a faster pace within the online fraternity [14]. (2018: 283-300). Furthermore, it stimulates students' thinking and discussions amongst students [14]. It is paramount to mention that the case presentation teaching method is frequently utilised in medicine [52].

Case-based is predominantly used where complex and interdisciplinary themes openly discussed [27]. Application oriented teaching platform became a reality in various university through online course construction [17].

According [55], civil engineering requires modern teaching methods such as hybrid, project, case and discussion into the classroom while utilising engineering examples to enhance teaching and learning.

\subsection{Project-based learning}

Project-based learning (PJBL) is a twenty-first century innovative learning approach that teaches various strategies to ensure students' success [56], particularly in higher learning environments. With this approach, students are afforded an opportunity to experience the reality of the real-world while boosting their communication skills and interdisciplinary learning [57]. However, PBL places more emphasis on learning through internal rather than external projects. Industrial collaboration projects build partnerships and provide opportunities to work on real problems, often seeking multidisciplinary approaches. This study explores and suggests the benefits that students derived from their participation in an external research and consultancy project at a University in Oman [57].

In 2016, Ralph conducted a research study looking into the post-secondary project-based learning in science, technology, engineering and mathematics [58]. The findings indicated that students benefitted from the project-based method regarding content knowledge, and interdisciplinary skills. Their learned skills would be instrumental in their future classes and career settings. However, most students did not enjoy the teamwork that PJBL brings but some learned from other group members [58]. All in all, the findings recommended that PJBL should be implemented institutionally rather than per discipline.

Typically, students using the project-based learning method work together as a team in order to solve the given problem by developing the product and development process [59]. PJBL is found to be an efficient teaching method in the twenty-first century as it promotes critical thinking, problem-solving skills, interpersonal communication, information and media literacy, collaboration, teamwork and leadership, creativity and innovation [60].

Other researchers conducted a study on Reform Practice of Engineering Drawing Courses in Chinese Colleges in 2019 [61]. The findings highlighted amongst others the emergence of the MOOC platform of outcomes-based education for engineering education models. All mechanical drawing courses implemented project-based teaching methods that were suited for the online environment. The MOOC platform catered from various online learning engagement models for a variety of questions, discussions sessions and projects [61].

\subsection{Inquiry-based learning}

The inquiry-based instructional approach is learner-centred and requires the learner to observe, generate questions, discover existing gaps and find appropriate resources to overcome these 
gaps [62]. These students take charge of their own learning by planning, monitoring and evaluating their progress made [63]. In 2017, researchers conducted a research study about preparing teacher-students for the $21^{\text {st }}$ century. An inquiry-based teaching method was utilised when 110 physics and chemistry teachers were involved. In their tasks, they managed to successfully explore and analyse the problems and formulated hypotheses and conducted their experiments. ICT applications were integrated by means of smart phones with cameras, laptop computers and software applications. As a result, the experiments were fruitful as they worked together with one common purpose [63].

It is a fact that in an inquiry-based phenomenon, students become their own teachers and take lead in the teaching and learning processes. The emergence of technology makes it easy for students to access their laboratory through the internet of things without them being in the physical laboratory [64-66]. It is imperative to note that virtual laboratory makes things bearable and cost-effective as compared to traditional laboratories as they are easy to maintain and safe to use. The science, engineering, and technology students find virtual laboratories user-friendly as they interact in inquiry-based classes where they can implement and analyse their own experiments and learn by using virtual objects and apparatus [67]. This teaching method also equips students with critical thinking, and innovative and team skills, which are valued for the twenty-first century job market [67]. A previous study initiated the STEM build website to coordinate online teaching and learning where instructors, markers, researchers, and Universal Design for Learning experts can easily interact [68].

Previously, engineering drawing was hand-based, now, online tutors are currently assisting these students. The utilisation of artificial intelligence makes it possible to provide real-time human-like feedback to students [69].

The emergence of the COVID-19 epidemic has seen the closure of campuses for schools and universities to ensure the safety of their students. As a result, online teaching and learning has become the reality in the 2020 academic year [70]. Online teaching and learning were found to be conducive for teaching students about circuits in electronic engineering [70] $(\mathrm{Hu}, 2020)$.

\subsection{Competency-based learning}

Over the past years, competency-based learning has rapidly gained momentum within the higher education space [71] and has been supported by ICT [74]. It is noticeable that over 896 institutions (universities and colleges) across the world prefer the competency-based learning method in their teaching and learning activities [71, 72]. Within competency-based learning, students depend more on their competency levels than on other people [21, 73]. Competency-based learning enables students to return to one or more competencies that are not yet mastered to avoid having to repeat courses as a result of failing [74]. Competency-based learning equips students with explicit and transferable learning objectives that provide them with personalised support and formative feedback so they can foster critical-thinking, problemsolving, communication and collaboration skills [74]. Competency-based models are dependent on measurable assessments linked to the related learning outcomes [75]. In most cases, competency-based learning is demonstrated through both formative and summative assessments [75]. However, at the
Minnesota State University, both assessments methods (summative and formative) were successfully utilised for the Honors Program to assess the competency level of the students over time through electronic portfolios. As such, this assessment method replaces the standard research thesis required in numerous traditional Honors Programs [76].

In most instances, the competency-based method is used by professional bodies to measure the level of acquired competencies of graduates regarding their required training expected in industries [77]. Employers like to state to the institutions of higher learning what competencies they expect from the graduates. Hence, the importance of institutions of higher learning to always consult the companies based on what they expect their graduates to possess is imperative [78].

\subsection{Communities of practice}

The communities of practice approach combine experiential learning, social constructivism and connectivism, which allows people to work together and give each other moral support [79] and compassion [80] as they study. This method permits students to put their skills into practice and largely share their experiences $[10$, 81]. Communities of practice (COP) allow the combination of experiential learning, social constructivism and connectivism can while demonstrating the limitations of classifying learning theories. In addition, COP allows group of engineers to work together in order to solve general challenges [81-84]. It is argued that for teaching and learning to effectively take place, precedence should be on cognitive, social and teacher presence [85].

\section{Research Methodology}

As mentioned before, the current study aims to determine teaching approaches in SET, which are gaining popularity due to the technological evolution over the years. It also aims to ascertain the state of distance education evolution with reference to technology adoption within the Science, Engineering and Technology qualifications in the institutions of higher learning. As mentioned earlier, engineering students were traditionally afforded opportunities to experientially practice learned knowledge in a laboratory setup. It is therefore of vital importance to assess the literature if science, engineering and technology students in higher education are to continue receiving laboratory experiments while studying in an online environment. The study targeted literature from 2010 to 2020 to determine teaching approaches that are gaining popularity in SET within an online environment. The reviewed literature was obtained from various search engines such as Google Scholar, Scopus, Sabinet, ProQuest and EBSCO.

The following search strings were used to search the openjournal sites:

- Teaching approaches for science, engineering and technology

- Teaching approaches for distance education

- Teaching technologies for SET in distance education

- Integrative approach for distance education in the SET

- discipline

- Apprenticeship and experiential learning for distance 
- $\quad$ education in SET

- Problem-based learning for distance education in SET

- Project-based learning for distance education in SET

- Competency-based learning for distance education in

- SET

- Inquiry-based learning for distance education in SET

- Case-based learning for distance education in SET

- Community of practice-based learning for distance

- education in SET

- $\quad \mathrm{AR}$ in SET

- $\quad$ VR in SET

- Virtual laboratory in SET

The research study concentrated only on journals that focussed on institutions of higher learning within the SET discipline. All other journal papers focussing on primary schools and industry were excluded from the study. The results of the reviewed literature were presented in both table and graph formats for appropriate analysis. Pareto analysis was conducted to determine teaching methods and their respective technologies preferred in the SET qualifications in an online environment.

\section{Research Findings and Discussion}

Theories such as cognitive behaviour, social constructivism and connectivism formed the basis of the different approaches discussed in the current study. It is clearly indicated that teaching approaches for SET always pay attention to the practical implications on what students theoretically learn in a class setup. The evolution of distance education has seen traditional teaching approaches such as competency-based learning, project-based learning, problem-based learning, inquiry-based learning, casebased learning, and apprenticeship and experiential learning as becoming relevant in the twenty-first century through technologies such as VR, AR, virtual laboratories, AM, FCM, Proteus software, Wolfson Open Science Laboratory, Virtual Microscope etc. It should be noted that the findings of this study are entirely based on the reviewed literature sources. The results in Table 1, depict how different approaches transited from traditional face-to-face to online virtual practical so that students could continue putting their knowledge into practice.

The results from both Figure 1 and Table 1 show the popularity of these teaching approaches in an online environment emerging from 2010 until recently. The results also display that problembased, apprenticeship and experiential learning, competencybased learning and inquiry-based learning are more popular in an online environment, particularly in SET. It suffices to mention that all highlighted teaching approaches are preferred in SET within online space but differ due to their popularity over the years.

Figure 1 elaborates on the popularity of teaching approaches suitable for online teaching and learning as per the author's contributions. The study results show that problem-based learning has gained popularity and exceeded all the other approaches, followed by apprenticeship and experiential approaches. The third important approach was found to be competency-based. However, case-based, project-based and community of practice-based approaches shared the fourth position for popularity. Last, but not the least, integrative approach proved to have less popularity. It is important to emphasise that all these approaches are applicable in an online environment within SET disciplines. It is evidence that from 2009,2010, 2011, 2012 these various teaching approaches were utilised mainly in face-to-face institutions. However, the emergence of the internet of things made it possible for utilising them for open and distance education, particularly 2017, 2019 and recently. In recent years as from 2015 until recent Virtual labs, virtual reality gave problem-based, apprenticeship and experiential learning as well as competency-based approaches impetus within the science and engineering space as seen in the table below. It is evidence from Figure 1 and Table 1 that other technologies such as LMS, FCM in education, 3D printers and $\mathrm{AM}$ in the manufacturing spaces continued to gain recognition as from 2016 and prominently in 2019 . The study rightfully, depicted the gap in open and distance learning environment where similar teaching approaches in science and engineering where applicable.

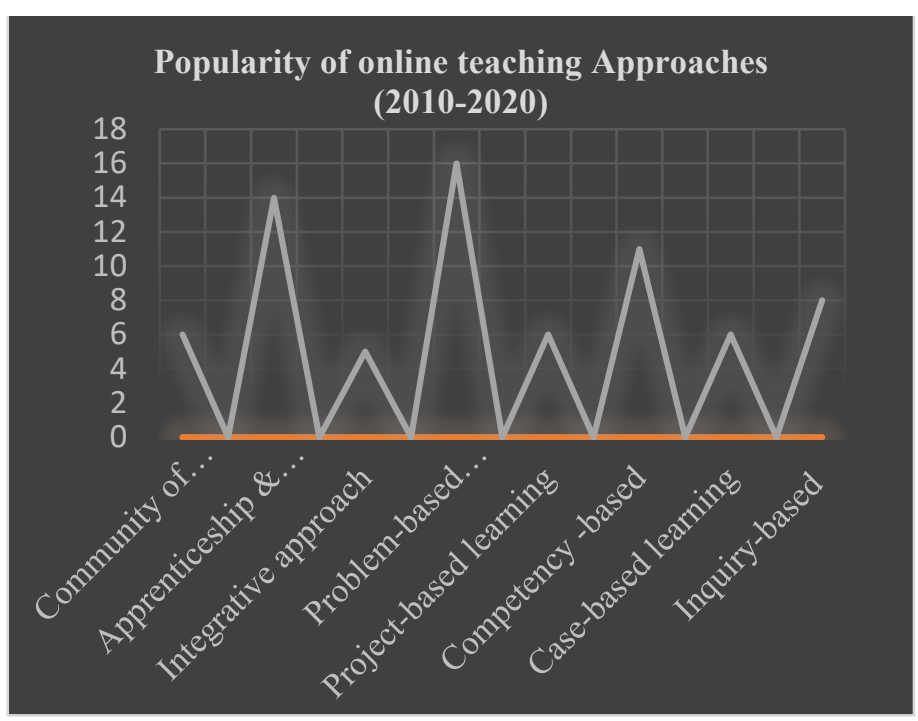

Figure 1: Popularity of teaching approaches

Table 1: Authors who endorsed teaching approaches

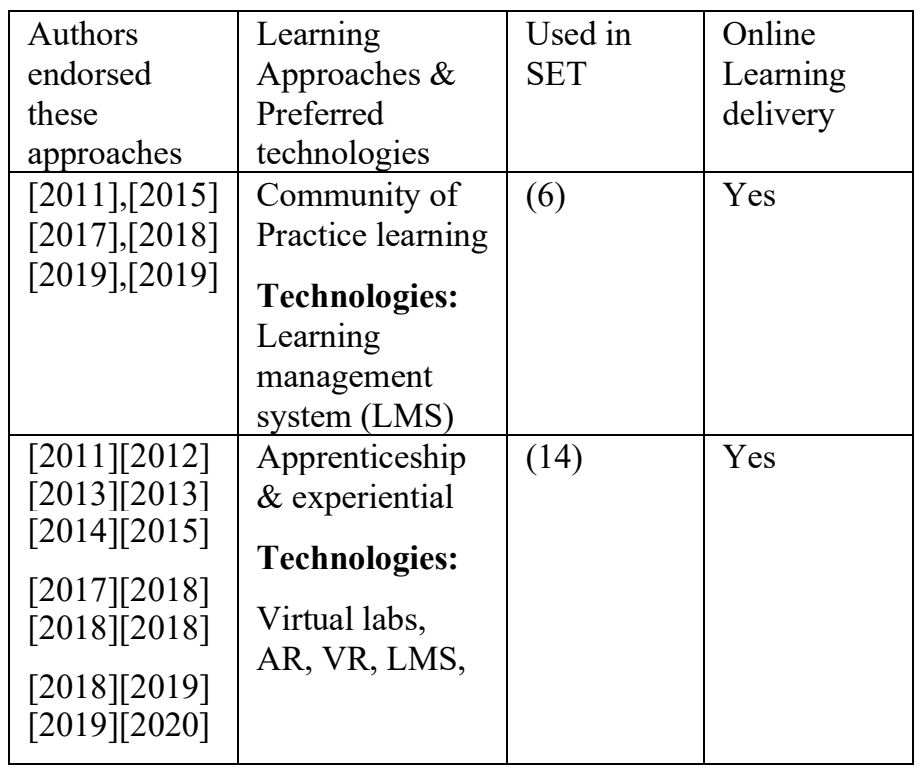




\begin{tabular}{|l|l|l|l|}
\hline$[2016][2017]$ & Integrative & $(5)$ & Yes \\
{$[2018][2018]$} & approach & & \\
{$[2019]$} & Technologies: & & \\
& $\begin{array}{l}\text { Virtual learning } \\
\text { Systems; 3D } \\
\text { printing }\end{array}$ & & \\
& Inquiry-based & $(8)$ & Yes \\
{$[2010][2017]$} & learning & & \\
{$[2017]$} & Technologies: & & \\
{$[2019][2018]$} & & \\
{$[2020]$} & LMS & & \\
\hline$[2012][2014]$ & Problem-based & $(16)$ & Yes \\
{$[2014][2015]$} & learning & & \\
{$[2015][2017]$} & Technologies: & & \\
{$[2015][2016]$} & AM; FCM; & & \\
{$[2016][2017]$} & Proteus & & \\
{$[2017][2018]$} & software; & & \\
{$[2018][2018]$} & Wolfson Open & & \\
{$[2019][2019]$} & Science & & \\
& Laboratory; & & \\
& Virtual & & \\
Microscope & & \\
\hline$[2010][2016]$ & Project-based & $(6)$ & Yes \\
{$[2016][2017]$} & learning & & \\
{$[2019][2020]$} & Technologies: & & \\
{$[2015][2015]$} & FCM and LMS & & \\
{$[2016][2016]$} & bompetency - & $(11)$ & \\
{$[2016][2016]$} & Technologies: & & \\
{$[2017][2016]$} & FCM and LMS & & \\
{$[2020]$} & & \\
\hline$[2011][2016]$ & Case-based & $(6)$ & \\
{$[2018][2018]$} & learning & & \\
{$[2019][2019]$} & Technologies: & & \\
& FCM and LMS & & \\
\hline
\end{tabular}

\section{Conclusion}

The emergence of the COVID-19 pandemic has provided an opportunity to many institutions to introduce various technologies to enhance teaching and learning activities for students and academics. Much more importantly, many institutions were not ready to offer non-venue-based examinations and remote laboratory practical. As a result, some institutions forged ahead and offered mid-year non-venue-based examinations while other institutions postponed all their examinations to October/November 2020. However, the issue of credible examination remained a concern to these institutions. These institutions want their students to write non-venue-based examinations, which are remotely invigilated by means of proctoring system to maintain their quality standards.
Equally important, institutions which offered campus-based practical experiments opted for alternative practical such as videobased and virtual practical to their students. Many of the institutions are only considering virtual practical now, as the COVID-19 situation does not show any sign of coming to an end soon. Hence, the importance of the current study so that institutions across the world can see various teaching approaches and technologies suitable for the online environment.

Traditionally, all practical experiments in science, engineering and technology institutions were conducted in physical laboratories. As such, most distance education institutions across the world collaborated with other campus-based institutions for their students to conduct laboratory work at those institutions, see Figure 1 and Table 1. However, such institutions always complained of the quality of practical work done in other institutions. In most cases, the Engineering Council of South Africa (ECSA) was concerned about the teaching and learning activities pertaining to engineering courses offered by distance education and those that were conducted online. ECSA, is a professional body that accredits all engineering qualifications in South Africa. They were more concerned about the practical work and the credibility of the assessments would ensue. Hence, the importance of the current study to publicise what other institutions across the world are doing regarding the virtual spaces utilising AR and VR technologies.

The findings of the current study indicate that virtual laboratories are the solution for most of the SET institutions operating in an online environment. The traditional teaching methods for civil engineering courses were no longer appropriate due to technological advancements [86]. Hence, the adoption of online courses for efficient learning. The introduction of microvideos and final assessment methods made it possible for students in other areas to be involved [86]. Notably, most of the distance education institutions are already employing teaching approaches such as problem-based (16), apprenticeship and experiential learning(14), competency-based learning (11), inquiry-based learning (8), community of practice learning (6), case-based learning (6) and integrative-based learning (5).

Education technology has made it possible for students to learn outside of the classroom when they are at home. Both synchronous and asynchronous learning allows students to access teaching materials in their own comfortable space [87]. The study confirmed that many students in the engineering discipline developed an interest in teaching and learning where they were exposed to various assessment methods, linking theory for practice and case discussion [86]. This statement shows that the introduction of new technologies within the institutions of learning are enabling students to perform better, see Figure 1 and Table 1. The usage of different teaching methods plays an important role towards students' performances [88].

Both students and academics show that instant feedback provided by virtual laboratories yielded encouraging results [67]. Virtual laboratories began to gain popularity as early as 2012 and increasingly so in this digital era. This shows that many students and their academics prefer the introduction of the virtual laboratories in their learning environment. The institutions of higher learning are challenged by the current dispensation where 
academics are expected to implement new pedagogical approaches and take advantage of ICT for teaching and learning, as can be seen in both Figure 1 and Table 1. As a result, these institutions need to equip the academics to be able to integrate technology within their teaching methods so that students continue to learn at ease. It is affirmed that the world-wide education system should incorporate the twenty-first century skills into curricula [63]. The current study acknowledges the challenges brought by the COVID-19 pandemic into the online institutions of learning, but the introduction of various teaching methods along with various technologies might bring relief if implemented correctly. Institutions are confronted with an opportunity to assess their current resources and equip their academics appropriately so that they can structure their assessments and practicals accordingly.

The current study proposes that a future study assess the implementation of various teaching approaches along their suitable technologies within the SET institutions in the southern Africa region.

\section{Conflict of Interest}

The authors declare no conflict of interest.

\section{Acknowledgment}

This research was made possible by the funding received from the National Research Foundation of South Africa and the research unit of the University of South Africa.

\section{References}

[1] M. G. Kanakana-Katumba, R. Maladzhi, "Online Learning Approaches for Science, Engineering and Technology in Distance Education," In 2019 IEEE International Conference on Industrial Engineering and Engineering Management (IEEM), 930-934. IEEE, 2019, doi.org/10.1109/IEEM44572.2019.8978892.

[2] C. Hall, W. Swart, S. Duncan, "Balancing customer needs and standards in higher education," Quality Approaches in Higher Education, 3(1), 2-7, 2012.

[3] E.I. Allen, J. Seaman, "Changing course: Ten years of tracking online education in the United States," Sloan Consortium. PO Box 1238, Newburyport, MA 01950, 2013.

[4] T. Kattoua, M. Al-Lozi, M., A.A. Alrowwad, "A review of literature on Elearning systems in higher education," International Journal of Business Management \& Economic Research, 7(5), 754-762, 2016

[5] P.A. Cohen, B.J. Ebeling, J.A. Kulik, A "meta-analysis of outcome studies of visual-based instruction," Educational Technology Research and Development, 29(1):26-36, 1981.

[6] J. Barbara, A. McNeil, "Meta-analysis of interactive video instruction: A 10 year review of achievement effects," PhD thesis, University of Idaho, 1989.

[7] S.W. Bonham, D.L. Deardorff, R.J. Beichner, "Comparison of student performance using web and paperbased homework in college-level physics," Journal of Research in Science Teaching, 40(10):1050-1071, 2003. https://doi.org/10.1002/tea.10120

[8] H. Fynewever, "A comparison of the effectiveness of web-based and paperbased homework for general chemistry," The Chemical Educator, 13(4):264-269, 2008.

[9] K. VanLehn, "The relative effectiveness of human tutoring, intelligent tutoring systems, and other tutoring systems," Educational Psychologist, 46(4), 197-221, 2011, doi.org/10.1080/00461520.2011.611369.

[10] T. Bates, "Second Wave of DE and History of the Open University," 2011.

[11] J.F. Heydenrych and P. Prinsloo, "Revisiting the five generations of distance education: Quo vadis ?," Progressio. 32(1):5-26, 2010.

[12] L.S. Mbati, "Exploring media blends for constructivist learning in open and distance e-learning (ODeL) environments," Diss, 2013.

[13] T. W. Argles, M. Brodeur, N. St J. Braithwaite, "Delivering authentic online practical science teaching-geoscience perspectives from the OpenScience Laboratory," In International Geological Congress, Abstracts, 35, 2017.

[14] N. Wengrowicz, W. Swart, R. Paul, K. Macleod, D. Dori, Y.L. Dori,
"Students' collaborative learning attitudes and their satisfaction with online collaborative case-based courses, " American Journal of Distance Education, 32(4), 283-300, 2018, doi.org/10.1080/08923647.2018.1511509.

[15] S. Jiang, J. Xu, "Construction and Commissioning of Engineering Graphics Online Course," In Education Teaching Forum, 12, 102-103, 2018.

[16] N. Brouwer, G. Fleerackers, N. H. Majcen, I. Maciejowska, C. McDonnell, and M. Mocerino, "Online course to improve university laboratory teaching practice,” VIRT\&L-COMM, 10, L-COMM, 2016.

[17] J. Wang, "Research on the classroom teaching reform of financial management" under the background of online course construction," Think Tank Era, 34, 66-67, 2019.

[18] R. Bose, "Virtual Labs Project: A Paradigm Shift in Internet-Based Remote Experimentation," Access IEEE, 1, 14, 2013 , doi.org/10.1109/ACCESS.2013.2286202.

[19] E.G. Dada, A.H. Alkali, D. O. Oyewola, "An Investigation into the Effectiveness of Asynchronous and Synchronous E-learning Mode on Students' Academic Performance in National Open University (NOUN)," Maiduguri Centre. International Journal of Modern Education \& Computer Science, 11(5), 2019. doi: 10.1002/tea.10120

[20] A. Mikroyannidis, A. Gómez-Goiri, A. Smith and J. Domingue, "Online experimentation and interactive learning resources for teaching network engineering," IEEE. Global Engineering Education Conference (EDUCON), Athens, 181-188, 2017, doi.org/10.1109/EDUCON.2017.7942845.

[21] T. Bates, "Teaching in a Digital Age: Guidelines for Designing and Learning," Tony Bates Associates Limited, 2019.

[22] A. Y. Kolb, D.A. Kolb, "The learning way: Meta-cognitive aspects of experiential learning," Simulation \& gaming, 40(3), 297-327, 2009, doi.org/10.1177/1046878108325713.

[23] A. Stern, Y. Rosenthal, N. Dresler, Ashkenazi, D, "Additive manufacturing: An education strategy for engineering students," Additive Manufacturing, 27, 503-514, 2019, doi.org/10.1016/j.addma.2019.04.001.

[24] N. Kholis, M. S. Zuhrie, R. Rahmadian, "Innovation Online Teaching Module Plus Digital Engineering Kit with Proteus Software through Hybrid Learning Method to Improve Student Skills," Materials Science and Engineering, 336, 012036, doi.org/10.1088/1757-899X/336/1/012036.

[25] G. Guler, C. Sen, Z.S. Ay, A. Ciltas, "Engineering Skills that Emerge During Model-Eliciting Activities (MEAs) Based on 3d Modeling Done with Mathematics Pre-Service Teachers," International Journal of Education in Mathematics, Science and Technology, 7(3), 251-270, 2019.

[26] L. Luo, "Analysis on Online and Offline Blended Teaching Design Taking Engineering Survey," Course of Non-surveying and Mapping Engineering Specialty as an Example. In 3rd International Conference on Culture, Education and Economic Development of Modern Society (ICCESE 2019), Atlantis Press, 2019.

[27] N. Mestrinho, B. Cavadas, "Innovation in Teacher Education: An Integrative Approach to Teaching and Learning Science and Mathematics," in Multidisciplinary Digital Publishing Institute Proceedings, 2(21), 1343, 2018, doi.org/10.3390/proceedings 2211343 .

[28] A.O. Akande, J.P. Van Belle, "The use of Software as a Service to Facilitate Quality Learning Experience for Students in Higher Education Institutions,"

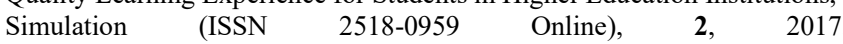
doi.org/10.24178/ijsms.2017.2.2.08.

[29] P. Padayachee, S. Wagner-Welsh, H. Johannes, "Online assessment in Moodle: A framework for supporting our students," South African Journal of Higher Education 32(5): 211-235, 2018, doi.org/10.1080/03043797.2015.1095162.

[30] R. Bhathal, "An appraisal of an online tutorial system for the teaching and learning of engineering physics in conjunction with contextual physics and mathematics, and relevant mathematics," European Journal of Engineering Education, 41(5), 504-511, 2016.

[31] S. Frerich, D. Kruse, M. Petermann, A. Kilzer, "Virtual Labs and Remote Labs: Practical experience for everyone," Proc. IEEE Global Engineering Education Conference (ED UCON), 312-314, 2014, doi.org/10.1109/EDUCON.2014.6826109.

[32] J. M. Marquez-Barja, N. Kaminski, F. Paisana, C. Tranoris and L. A. DaSilva, "Virtualizing testbed resources to enable remote experimentation in online telecommunications education," Proc. IEEE Global Engineering Education Conference (EDUCON), 836-843, 2015 , doi.org/10.1109/EDUCON.2015.7096069.

[33] L. Li, Y. Chen, Z. Li, D. Li, F. Li, H. Huang, "Online Virtual Experiment Teaching Platform for Database Technology and Application," 13th International Conference on Computer Science \& Education (ICCSE), Colombo, 1-5, 2018. http://dx.doi.org/10.1109/ICCSE.2018.8468849

[34] G. Altuger-Genc, Y. Han, Y. Genc, "Towards Simulation Aided Online Teaching: Material Design for Applied Fluid Mechanics," International 
Journal of Online and Biomedical Engineering (iJOE), 14(12), 112-125. 2018, doi.org/10.3991/ijoe.v14i12.8630.

[35] M. Hincapié, A. Caponio, H. Rios, E.G. Mendívil, "An introduction to Augmented Reality with applications in aeronautical maintenance," In 2011 13th International Conference on Transparent Optical Networks, 1-4, IEEE, 2011, doi.org/10.1109/ICTON.2011.5970856.

[36] I. Sanchez-Rola, M. Dell'Amico, P. Kotzias, D. Balzarotti, L. Bilge, P.A. Vervier, I. Santos. "Can I Opt Out Yet? GDPR and the Global Illusion of Cookie Control," In Proceedings of the 2019 ACM Asia Conference on Computer and Communications Security, 340-351, 2019.

[37] H.K. Wu, S.W.Y. Lee, H.Y. Chang, J.C. Liang, "Current status, opportunities and challenges of augmented reality in education," Computers \& education, 62, 2013, 41-49, doi.org/10.1016/j.compedu.2012.10.024.

[38] R. Azuma, R. n.d, "A Survey of Augmented Reality. iitk.ac.in". Retrieved August 2020.

[39] T. Olsson, T. Kärkkäinen, E. Lagerstam, L.Ventä-Olkkonen, "User evaluated of mobile augmented reality scenarios" Journal of Ambient Intelligence and Smart Environments, 4, 2012, 29-47.

[40] N.S. Ismail, J. Harun, M.A.Z.M. Zakaria, and S.M. Salleh, "The effect of Mobile problem-based learning application DicScience PBL on students' critical thinking," Thinking Skills and Creativity, 28, 177-195. 2018, doi.org/10.1016/j.tsc.2018.04.002.

[41] S. Han, R. Capraro, M.M. Capraro, "How science, technology, engineering, and mathematics (STEM) project-based learning (PBL) affects high, middle, and low achievers differently: The impact of student factors on achievement," International Journal of Science and Mathematics Education, 13(5), 10891113, 2015, doi.org/10.1007/s10763-014-9526-0.

[42] S. Ford, T. Minshall, "Invited review article: Where and how 3D printing is used in teaching and education," Additive Manufacturing, 25, 131-150. 2019, doi.org/10.1016/j.addma.2018.10.028.

[43] J. Bergmann, A. Sams, "Flip your classroom: Reach every student in every class every day International Society for Technology in Education," Washington, DC, 2012.

[44] S.J. DeLozier, M.G. Rhodes, "Flipped classrooms: A review of key ideas and recommendations for practice," Educational Psychology Review (2016), 1-11, doi.org/10.1007/s10648-015-9356-9.

[45] Y. Chen, Y. Wang, Kinshuk, N.S. Chen, "Is FLIP enough? Or should we use the FLIPPED model instead?" Computers \& Education, 79, 16-27, 2014, doi.org/10.1016/j.compedu.2014.07.004.

[46] M. Katsa, S. Sergis, D.G, Sampson. "Investigating the potential of the flipped classroom model in K-12 mathematics teaching and learning Proceedings of the 13th international conference on cognition and exploratory learning in digital age", 2016.

[47] T. Muir, V. Geiger, "The affordances of using a flipped classroom approach in the teaching of mathematics: A case study of a grade 10 mathematics class," Mathematics Education Research Journal, 28(1), 149-171, 2016 doi.org/10.1007/s13394-015-0165-8.

[48] M.N. Giannakos, J. Krogstie, N. Chrisochoides. "Reviewing the flipped classroom research: Reflections for computer science education," Proceedings of the computer science education research conference, 23-29, 2014, doi.org/10.1145/2691352.2691354.

[49] S. Reza, M.I. Baig, "A study of inverted classroom pedagogy in computer science teaching," International Journal of Research Studies in Educational Technology, 4(2), 19-30, 2015, doi.org/10.5861/ijrset.2015.1091.

[50] V. Aidinopoulou, D.G. Sampson, "An action research study from implementing the flipped classroom model in primary school history teaching and learning," Journal of Educational Technology \& Society, 20(1), 237-247, 2017.

[51] S., Sergis, D.G. Sampson, L. Pelliccione, "Investigating the impact of Flipped Classroom on students' learning experiences: A Self-Determination Theory approach," Computers in Human Behavior, 78, 368-378, 2018, doi.org/10.1016/j.chb.2017.08.011.

[52] B. Turk, S. Ertl, G. Wong, P.P. Wadowski, H. Löffler-Stastka, "Does casebased blended-learning expedite the transfer of declarative knowledge to procedural knowledge in practice?" BMC Medical Education, 19(1), 1-10, 2019, doi.org/10.1186/s12909-019-1884-4.

[53] G. Marcus, R. Taylor, A. Ellis, "Implications for the design of online case based learning activities based on the student blended learning experience," in Beyond the comfort zone: Proceedings of the 21 st ASCILITE Conference, 557-586, 2004.

[54] P. Nicklen, J.L. Keating, S. Paynter, M. Storr, S. Maloney, "Remote-online case-based learning: a comparison of remote-online and face-to-face, casebased learning-a randomized controlled trial," Education for Health, 29(3), 195, 2016.

[55] Newson, T.A, N.J. Delatte, "Case methods in civil engineering teaching," www.astesj.com
Canadian Journal of Civil Engineering, 38(9), 1016-1030, 2011.

[56] S. Bell, "Project-based learning for the 21 st century: Skills for the future," The clearing house, $\mathbf{8 3}(2), \quad 39-43, \quad 2010$, doi.org/10.1080/00098650903505415.

[57] R. Belwal, S. Belwal, A.B. Sufian, A. Al Badi, "Project-based learning (PBL): outcomes of students' engagement in an external consultancy project in Oman," Education and Training, 2020.

[58] R. A. Ralph, "Post-secondary project-based learning in science, technology, engineering and mathematics," Journal of Technology and Science Education, 6(1), 26-35, 2016, doi.org/10.3926/jotse.155.

[59] D. Kokotsaki, V. Menzies, A. Wiggins, "Project-based learning: A review of the literature Improving Schools," 19(3) (2016), 267-277.

[60] S. K.W. Chu, R.B. Reynolds, N.J. Tavares, M. Notari, C.W.Y. Lee, "21st Century skills development through inquiry-based learning," Singapore: Springer Singapore. 2017, doi.org/10.1007/978-981-10-2481-8.

[61] Y. Dong, J. Song, S. Yi, X. Li, "Reform Practice of Engineering Drawing Courses in Chinese Colleges by the Blended Teaching Method with Different Teaching Modes and Resources Based on the XuetangX MOOC Platform," In 2019 2nd International Conference on Education, Economics and Social Science (ICEESS 2019). Atlantis Press, 2019, doi.org/10.2991/iceess-19.2019.70.

[62] C.E. Hmelo-Silver, C.A. Chinn, Chan, A.M. O’Donnell, "International handbook of collaborative learning," New York, NY: Routledge, 2013, doi.org/10.4324/9780203837290.

[63] P. Häkkinen, S. Järvelä, K. Mäkitalo-Siegl, A. Ahonen, P. Näykki, T. Valtonen, "Preparing teacher-students for twenty-first-century learning practices (PREP 21): A framework for enhancing collaborative problemsolving and strategic learning skills Teachers and Teaching," 23(1), 25-41, 2017, doi.org/10.1080/13540602.2016.1203772.

[64] C. Soudien, "Transformation in higher education : A briefing paper," 2010.

[65] K. Kaen, "A Contextual O nline Game based on Inquiry Learning Approach for Improving Students' Learning Performance in a Chemistry Course," 601608, 2017.

[66] V. Fruiht, "Project-Based Curriculum as a Guide for the Re-Sequencing of Discipline-Specific Statistics Courses," 2018.

[67] T. Lynch, I. Ghergulescu, "Review of virtual labs as the emerging technologies for teaching STEM subjects," In INTED2017 Proc. 11th Int. Technol. Educ. Dev. Conf. 6-8 March Valencia Spain, 6082-6091, 2017, doi.org/10.21125/inted.2017.1422.

[68] M. V. Ramirez, C.L. Gordy, "STEM build: an online community to decrease barriers to implementation of inclusive tactile teaching tools," Journal of Microbiology \& Biology Education, 21(1), 2020, doi.org/10.1128/jmbe.v21i1.1963.

[69] E. Hilton, B. Williford, W. Li, T. Hammond, J. Linsey, "Teaching Engineering Students Freehand Sketching with an Intelligent Tutoring. Inspiring Students with Digital Ink: Impact of Pen and Touch on Education", $135,2019$.

[70] H. Hu, S., Song, Y. Chai, Y. Gong, "Study on Online Teaching of High Frequency Circuit under COVID-19 Epidemic", Open Journal of Social Sciences, 8(3), 493-496, 2020, doi.org/10.4236/jss.2020.83041.

[71] T.R. Nodine, "How did we get here? A brief history of competency-based higher education in the United States," The Journal of Competency-Based Education, 1(1), 5-11, 2016, doi.org/10.1002/cbe2.1004.

[72] R, Kelchin, 2015, "The landscape of competency-based education: Enrollments, demographics, and affordability," Washington, DC: American Enterprise Institute.

[73] S. Directors, C. Technical, E. Consortium, "Building a strong competencybased pathways and career," 2015.

[74] P. Williams, "Does competency-based education with blockchain signal a new mission for universities?" Journal of higher education policy and management, $\quad \mathbf{4 1}(1), \quad 104-117, \quad 2019$, doi.org/10.1080/1360080X.2018.1520491.

[75] A.A. Kytmanov, M.V. Noskov, K.V. Safonov, M.V., Savelyeva, V.A. Shershneva, "Competency-based learning in higher mathematics education as a cluster of efficient approaches," Bolema: Boletim de Educação Matemática, 30(56), 1113-1126, 2016, doi.org/10.1590/1980$4415 \mathrm{v} 30 \mathrm{n} 56 \mathrm{a} 14$.

[76] G. Walters, "Developing competency-based advising practices in response to paradigm shifts in higher education,” NACADA Journal, 36(1), 66-79, 2016, doi.org/10.12930/NACADA-15-033.

[77] S. Perera, S.O. Babatunde, J. Pearson, D, Ekundayo, "Professional competency-based analysis of continuing tensions between education and training in higher education," Higher Education, Skills and Work-Based Learning, 2017, doi.org/10.1108/HESWBL-04-2016-0022.

[78] J. Henrich, "Competency-based education: The employers' perspective of 1215 
higher education," The Journal of Competency-Based Education, 1(3), 122129, 2016, doi.org/10.1002/cbe2.1023.

[79] D, Brittany, J.E. Coryell, "Relationships, Participation, and Characteristics of a Community of Practice in S hort-Term Adult Study Abroad," Adult Learning, 2019.

[80] A. ettit, A. McVicar, P. Knight-Davidson, A. Shaw-Flach. "Releasing Latent Compassion through an Innovative Compassion Curriculum for Specialist Community Public Health Nurses," Journal of Advanced Nursing 75(5), 53$62,2019$.

[81] B.W. Trayner, "Communities of practice a brief introduction," 1-8, 2015.

[82] A. Cox, "What are communities of practice? A critical review of four seminal works. Paper presented at the Fifth European Conference on Organizational Knowledge, Learning, and Capabilities," in Fifth European Conference on Organizational Knowledge, Learning, and Capabilities, 2004.

[83] B.W. King, "Communities of Practice," no. August, 2017.

[84] L. Leonard, C. Kies, N. Braaf, "Reflections: eLearning Colloquia enhance a Community of Practice," 2018, doi.org/10.4324/9780429283499-2.

[85] D. R. Garrison, M. C. Leveland-Innes, "Facilitating Cognitive Presence in Online Learning : Interaction Is Not Enough in Online Learning : Interaction Is Not Enough,” Am. J. Distance Educ., 19(3), 133-148, 2005.

[86] C.H.E.N. Tao, L.I. Ju-xuan, "Teaching Reform in the Course of Civil Engineering Introduction Under the Background of Online Courses," In International Conference on Modern Educational Technology and Innovation and Entrepreneurship (ICMETIE 2020), 76-80, Atlantis Press, 2020.

[87] M.M. Sahabadi, M. Uplane, "Synchronous and Asynchronous e-learning Styles and Academic Performance of e-students. Procedia - Social and Behavioral Sciences", 176, 129-138, 2015.

[88] P. Ahmadi, K.I, Yousaf, "An Empirical Study of Teaching Methodologies and Learning Outcomes for Online and in-class Networking Course Sections," arXiv preprint arXiv:1711.11411, 2017.

[89] Y, Grossman, "Introduction to flavour physics," In LHC Phenomenology, 35-80. Springer, Cham, 2015, doi.org/10.1007/978-3-319-05362-2_2

[90] P. Fain, "Moving ahead with competency," Inside Higher Education, 2015, https://www.insidehighered.com/news/2015/02/17/two-year-collegeswashington-state-expand-competency-based-project-business-degree

[91] T. Mitchell, "Guidance to competency-based education experimental site released," Home Room, the official blog of the U.S. Department of Education, 2015. 